\title{
Bracket/wire play: What to expect from tipping prescription on pre-adjusted appliances
}

Leopoldino Capelozza Filho', Fabricio Monteiro de Castro Machado², Terumi Okada Ozawa³, Arlete de Oliveira Cavassan4, Mauricio de Almeida Cardoso ${ }^{5}$

Introduction: The opinion on the 'straight-wire' concept has been evolving since its origin, characterized by faithful followers or absolute skepticism. Currently, it seems reasonable to state that most professionals have a more realistic and critical viewpoint, with an attitude that reveals Orthodontics' maturity and greater knowledge on the technique. The most relevant criticisms refer to the impossibility of the both the Straight-Wire and the Standard systems to completely express the characteristics related to the brackets due to mechanical deficiencies, such as bracket/wire play.

Objectives: A critical analysis of this relationship, which is unclear due to lack of studies, was the scope of this paper.

Methods: The compensatory treatment of two patients, using Capelozza's individualized brackets, works as the scenery for cephalometric evaluation of changes in incisor inclination produced by different dimensions of leveling archwires.

Results: The evaluation of these cases showed that, while the introduction of a $0.019 \times 0.025$-in stainless steel archwire in a $0.022 \times 0.030$-in slot did not produce significant changes in incisor inclination, the $0.021 \times 0.025$-in archwire was capable of changing it, mainly in mandibular incisors, and in the opposite direction to the compensation.

Conclusion: Considering compensatory treatments, even when using an individualized prescription according to the malocclusion, the bracket/wire play seems to be a positive factor for malocclusion correction, without undesirable movements. Therefore, it seems reasonable to admit that, until a bracket system can have absolute individualization, the use of rectangular wires that still have a certain play with the bracket slot is advisable.

Keywords: Orthodontic brackets. Orthodontics. Rectangular wires.

${ }^{1}$ MSc in Orthodontics, Bauru Dentistry School. PhD in Dental Rehabilitation, Bauru Dentistry School. Professor of Dental Undergraduate Program, Specialization Program and MSc Program at the Sacred Heart University.

${ }^{2}$ Professor of Specialization Programs in Orthodontics at the Maringá University Center (CESUMAR) and at Marília University (UNIMAR).

${ }^{3}$ Head Professor of the Dental Division of Hospital of Rehabilitation of Craniofacial Anomalies, USP.

${ }^{4}$ Orthodontist at the Hospital of Rehabilitation of Craniofacial Anomalies, USP.

${ }^{5} \mathrm{MSc}$ and PhD in Orthodontics - UNESP, Araçatuba. Professor of Dental Undergraduate Program, Specialization Program and MSc Program at the Sacred Heart University.
How to cite this article: Capelozza Filho L, Machado FMC, Ozawa TO, Cavassan AO, Cardoso MA. Bracket/wire play: What to expect from tipping prescription on pre-adjusted appliances. Dental Press J Orthod. 2012 July-Aug;17(4):85-95.

Submitted: April 1, 2010 - Revised and accepted: February 15, 2012
» The authors report no commercial, proprietary or financial interest in the products
or companies described in this article.
" Patients displayed in this article previously approved the use of their facial and in-
traoral photographs.

Contact address: Leopoldino Capelozza Filho

Rua Dr. Servio Túlio Carrijo Coube, 2-70 - Jd. Infante D. Henrique

Bauru/SP - Brazil - CEP: 17.012-632 - E-mail: lcapelozza@yahoo.com.br 


\title{
Folga braquete/fio: o que esperar da prescrição para inclinação nos aparelhos pré-ajustados
}

\author{
Leopoldino Capelozza Filho', Fabricio Monteiro de Castro Machado², Terumi Okada Ozawa ${ }^{2}$, Arlete de Oliveira Cavassan4, \\ Mauricio de Almeida Cardoso ${ }^{5}$
}

Introdução: a opinião sobre o conceito Straight-Wire tem evoluído desde sua origem, caracterizada por seguidores fiéis ou ceticismo absoluto. Atualmente, parece razoável acreditar que a maioria dos profissionais tem uma visão mais realista e crítica, com uma postura que revela maturidade da Ortodontia e maior conhecimento sobre a técnica. As maiores críticas, e com fundamento, referem-se à impossibilidade do sistema, seja Straight-Wire ou Edgewise, expressar totalmente as características embutidas nos braquetes, devido a deficiências mecânicas como folga entre braquetes e fios.

Objetivos: uma análise crítica dessa relação mal explicada, pela carência de estudos, foi o escopo desse artigo.

Métodos: o tratamento compensatório de dois pacientes, realizados com braquetes individualizados Capelozza, serve de cenário para uma avaliação cefalométrica das alterações nas inclinações dos incisivos produzidas por diferentes calibres de arcos de nivelamento.

Resultados: a avaliação dos casos mostrou que, enquanto a introdução do arco de nivelamento de aço 0,019” X 0,025” em canaleta 0,022” X 0,030" não produziu alterações significativas nas inclinações dos incisivos, o arco 0,021” X 0,025”foi capaz de alterá-las, principalmente nos incisivos inferiores, e em direção contrária ao sentido da compensação.

Conclusão: em tratamentos compensatórios, mesmo buscando-se utilizar prescrição individualizada de acordo com a má oclusão, a folga entre braquete e fio parece ser um fator positivo para que ocorra a correção da oclusão, sem que movimentos indesejáveis aconteçam. Assim, parece razoável admitir que, até que um sistema de braquetes permita ter uma individualização absoluta, é recomendável a utilização de fios retangulares que preservem uma folga com a canaleta do braquete.

Palavras-chave: Braquetes ortodônticos. Ortodontia. Fios retangulares.

${ }^{1}$ Mestre em Ortodontia, FOB/Bauru. Doutor em Reabilitação Oral, FOB/Bauru. Professor do Programa de Graduação e Pós-graduação em nível de Especialização e Mestrado em Ortodontia, Universidade do Sagrado Coração, Bauru/SP.

${ }^{2}$ Professor dos cursos de Graduação em Odontologia e Especialização em Ortodontia do CESUMAR.

${ }^{3}$ Responsável pela Divisão Odontológica do HRAC-USP, Bauru/SP.

${ }^{4}$ Ortodontista do HRAC-USP, Bauru/SP.

${ }^{5}$ Mestre e Doutor em Ortodontia, UNESP/Araçatuba. Professor do Programa de Graduação e Pós-graduação em nível de Especialização e Mestrado em Ortodontia, Universidade do Sagrado Coração, Bauru/SP.
Como citar este artigo: Capelozza Filho L, Machado FMC, Ozawa TO, Cavassan AO, Cardoso MA. Bracket/wire play: What to expect from tipping prescription on preadjusted appliances. Dental Press J Orthod. 2012 July-Aug;17(4):85-95.

Enviado em: 1 de abril de 2010 - Revisado e aceito: 15 de fevereiro de 2012 » Os pacientes que aparecem no presente artigo autorizaram previamente a publicação de suas fotografias faciais e intrabucais.

»O primeiro autor é idealizador das prescrições de braquetes utilizadas nos tratamentos dos pacientes apresentados no artigo.

Endereço para correspondência: Leopoldino Capelozza Filho Rua Dr. Servio Túlio Carrijo Coube, 2-70, Jd. Infante D. Henrique - Bauru/SP CEP: 17.012-632 - E-mail: lcapelozza@yahoo.com.br 


\section{INTRODUCTION}

The rationale of straight wire mechanics is to adequately position teeth without the need of bending orthodontic archwires, transferring to the brackets the ideal positioning characteristics for each tooth at treatment completion. These characteristics, including angulation, inclination, inset and offset, present in each bracket, determine the so-called prescription.

Andrews's ${ }^{2}$ original proposal ${ }^{2}$ acknowledged differences in the movements that should be performed to the teeth to meet the therapeutic goals, which in turn were also distinct according to the malocclusion. Within this context, the author offered multiple brackets with different angulation and inclination prescriptions, which when combined allowed an extensive and varied range of combinations that might be called individualized. In practice, it seems that the wide use of these resources was not adopted. The probable cause for this was the premise that it might be possible to treat all patients with a single set of brackets, which would be much more convenient and simple.

Since the introduction of the straight wire appliance, several alterations were suggested for inclination and angulation values in the different prescriptions, in the attempt of treating the greatest number of cases without the need to include bends in leveling archwires. The great number of prescriptions currently available in the market, with such different values, reveals that this subject is far from reaching unanimity. The impossible search for a prescription that may be adequate to all cases still exists, though widely criticized in the literature, since it opposes the extensive morphological diversity of mankind, including face and obviously teeth.

Primary and usually unclear differences underlying these prescriptions should be considered. Some authors' intention is to alter the values of prescriptions individualizing the brackets according to the type of movement to be performed (individualization for movement) or according to the tooth positioning foreseen at treatment completion (individualization for finishing). Both might be useful when justified by the therapeutic goals.

These variations in prescriptions most of the times include variations in inclination and angulation. Others, such as in and out differences to control rotation during movement, seems to have been originated and restricted to Andrews ${ }^{2}$ appliance. An exception to this rule is the absence of molar off-set adopted for maxillary molars finalized in Class II molar relationship, specific and non-controversial.

One of the criticisms associated to the straight wire technique refers to the prescription expression capacity, since in most cases treatment is not conducted up to the thickest archwires, and even in that case, inherent deficiencies of the edgewise system such as play and force reduction would preclude the complete prescription expression. The expression of inclination seems to be more critical, being object of greatest controversies and will be addressed in this paper.

Conversely, when the subject is variation in prescriptions, tooth positioning at treatment completion seems to be an essential consideration. The last decade has enlightened the orthodontic community with a clear perception on the limitations of growth manipulation, evidencing the compensatory characteristics present at completion of the so-called "orthopedic-in treatments in patients with skeletal malocclusions. Within this context, the treatment goals for these patients should be revised. The acceptance of differential values for the buccolingual inclination of incisors as a characteristic of compensation of the remaining maxillo-mandibular discrepancy, implies an alteration of the desirable or possible inclination for these teeth at treatment completion, reinforcing the concept of individualization according to the type of malocclusion to be treated. In these cases, besides alignment and leveling, the brackets also assist on the establishment of compensation characteristics, when these are not yet present, or on their maintenance when they are already present as a result of previous orthopedic approaches or even natural compensation.

\section{The concept of play}

An important mechanical deficiency that has been more discussed in the literature after introduction of the straight wire technique is the play between the leveling archwire and the bracket slot. This makes sense, considering that in the edgewise technique the archwire was torqued as necessary, while theoretically it would not be manipulated in the straight wire technique. This play, also called deviation angle, was defined as a rotation movement of the rectangular archwire from its passive position (transverse section of 
archwire parallel to the slot walls) to a position where two opposite edges of the archwire contact two opposite walls of the bracket $\operatorname{slot}^{16}$ (Fig 1 ).

Initially, calculations using mathematical equations, considering brackets and archwires' nominal values, provided the first play values between archwire and bracket slot. ${ }^{11}$ However, when examining the actual dimensions of brackets and archwires, it was observed that the nominal values did not correspond exactly to their dimensions. There is some variation around the nominal value, called tolerance limit of manufacturers. This would occur because the manufacturers fabricate archwires which dimensions are never greater than nominal values, and bracket slots slightly greater than nominal values. This would avoid problems at insertion and removal of archwires, especially the larger ones, besides providing adequate depth to allow correct positioning in the slot. ${ }^{19}$ However, the tolerance values of manufacturers tend to increase the play values. ${ }^{10,11}$

When the method employed to analyze the play first involved a torque meter and not a mathematical equation, even higher play values were found. ${ }^{14}$ The explanation for such different values was that the archwires, when microscopically analyzed, exhibited beveled edges that would reduce its torque capacity, increasing the play. This occurs due to the manufacturing process of rectangular archwires, which are

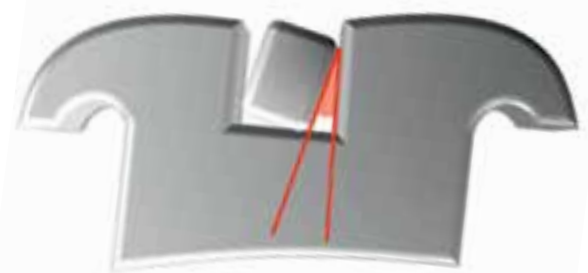

Figure 1 - The play (deviation angle) can be defined as an angular rotation of the wire, from its passive position (cross-section of the wire parallel to the slot walls) until the position where the diagonal corners of the wire contact the opposite wall of the slot. obtained by grinding a round archwire of greater diameter. ${ }^{19}$ Therefore, the edge remains rounded, evidencing that the Edgewise technique is not quite a sharp edge technique. This rounding of the edge could contribute for varied play values depending on the archwire composition. ${ }^{19}$ Combined to these factors, the concept of force reduction would also act reducing the capacity of torque expression..$^{9}$ Table 1 presents the play values found in the literature and the different methods employed for measurement.

Recognizing these limitations and considering that they would be more significant in teeth submitted to extensive movements, Andrews ${ }^{2}$ designed brackets with compensatory characteristics of mesiodistal contra-angulation, buccolingual contra-inclination and anti-rotation for cases involving tooth translation, so that at treatment completion teeth would have in correct positioning.

Other authors, considering the same mechanical deficiencies, suggested changing the prescription values to enhance the torque control, especially during anterior retraction mechanics. Concerning the inclination of maxillary incisors, Roth $;^{18}$ Mclaughlin, Bennett, Trevisi ${ }^{15}$ and Ricketts ${ }^{17}$ suggested different increases in the inclination values to obtain better torque control in anterior retraction movements. For mandibular incisors, Mclaughlin, Bennett, Trevisi ${ }^{15}$ and Alexander ${ }^{1}$ suggested a reduction in Andrews ${ }^{2}$ original value. The explanation for this individualization would be controlling an effect considered undesirable by the authors: The buccal inclination of mandibular incisors during leveling. As far as it is known, this explanation lacks rationale, considering that, initial leveling archwires are round or have reduced dimensions, not exerting any control on the buccal inclination of incisors. This reduced inclination would further act as a resistant negative torque during the use of Class II elastics, which may or not be useful depending on the therapeutic intention. Regarding compensatory treatments, this inclination lacks logic, especially after growth completion.

Table 1 - Compilation of play values reported in the literature.

\begin{tabular}{cccc} 
Author & Method & $\mathbf{0 . 0 1 9}$ x 0.025-in archwire & 0.021 x 0.025-in archwire \\
& & x 0.022-in slot & x 0.022-in slot \\
\hline Dellinger & Mathematical calculation based on nominal values & $7.88^{\circ}$ & $2.93^{\circ}$ \\
Dellinger $^{11}$ & Mathematical calculation based on maximum tolerance values & $9.63^{\circ}$ & $4.32^{\circ}$ \\
Creekmore $^{10}$ & Data provided by Unitek, considering the tolerance values & $10.5^{\circ}$ & $3.9^{\circ}$ \\
Hixson et al ${ }^{14}$ & Torque meter & $12.8^{\circ}$ & $8.4^{\circ}$ \\
Sebanc et al ${ }^{19}$ & Torque meter & $10.9-23.9^{\circ}$ & $4.5-8.3^{\circ}$ \\
\hline
\end{tabular}


In summary, it should be recognized that all these individualizations are designed for movement. The difference between these authors is that Mclaughlin, Bennett and Trevisi ${ }^{15}$ ruled out the need to manage the angulation for individualizing the movement, adopting only the management of inclination. However, all authors have made a mistake against the essence of the straight wire concept, when determining that these brackets could or should be used generically.

\section{Biological variation}

In addition to the mechanical deficiencies of the edgewise technique, another great criticism to the straight wire appliance was the mistaken concept that extrapolates its author's ${ }^{2}$ concept ,that a single prescription could be suitable to all patients, ignoring, for example, the wide biological variation demonstrated in buccal surface contours of teeth. ${ }^{11,21,22}$ In all studies, the standard deviation was significant and increasing in anteroposterior direction, ${ }^{11,21,22}$ precluding the use of mean values as a rule, since identical bracket bases would adjust differently on each tooth surface. Therefore, the authors conclude that the use of reduced diameter archwires, allowing a certain play between archwire and bracket slot, is the mechanical property that allows the use of straight wire appliances in a large number of cases without causing undesirable effects.

Andrews, ${ }^{2}$ in his original paper, also comments on the wide variation existing in the inclinations of buccal surfaces of clinical crowns, yet in his studies the greatest variation was concentrated on the incisors region and was not related to variations in the buccal surface contour, of clinical crowns but rather to changes in the dental inclinations of incisors, as a compensating mechanism in cases of small to moderate discrepancy between the bone bases. For these cases, Andrews ${ }^{2}$ designed a variation of regular brackets with differential values for the inclination of incisors. This is one among several evidences that the author recognized the impossibility to apply with excellence a single set of brackets to all patients.

Bibby, ${ }^{3}$ Casko and Shepperd ${ }^{8}$ reported variations in the inclination of incisors in different skeletal patterns, clearly demonstrating the incisor compensation capacity in cases of small to moderate sagittal discrepancy, with the clear goal to maintain an adequate overjet. Solow $^{20}$ discusses that using cephalometric norms for positioning incisors to achieve ideal outcomes in cases of skeletal discrepancy is a great mistake. According to Handelman ${ }^{12}$ and Capelozza, ${ }^{5,7}$ the most adequate positioning parameter would be never surpassing the biological limits during treatment, determined by the positioning of buccal and lingual cortical plates. Clinical monitoring, with evaluation of periodontal quality and primarily considering the attached gingiva, might define the limits and type of movement.,

\section{Individualization}

In 1999, Capelozza Filho ${ }^{5}$ reintroduced the concept of individualization for finishing. His prescription is based on the same individualization concept for finishing originally proposed by Andrews, ${ }^{2}$ i.e. altering the inclination values of incisors to compensate an altered bone base relationship. It is known, from clinical and research standpoints, ${ }^{4}$ that cases finalized with excellence may present extreme variations in inclination, especially for mandibular incisors. Also, the author ${ }^{5}$ suggests individualizing the angulation, a new and very important concept to generate or consume space, avoiding or potentiating tooth movements according to the therapeutic intentions. The angulations of maxillary and mandibular canines and incisors are altered to allow these teeth to occupy more or less space according to the specific need. As a consequence of the decision of angulating a tooth, there will be spontaneous repercussions in the movement of this tooth and adjacent teeth and other non-spontaneous repercussions that should be recognized and managed by the orthodontist. ${ }^{5,6,7}$ More recently, a new bracket for maxillary canines (zero angulation) was introduced for maximum compensation (minimum protrusion) in the compensatory treatment of Pattern II malocclusions (Tabs 2 and 3).

The author considers that angulation is a more important individualization aspect than inclination because of its earlier manifestation, since the first archwire; more constant and progressive, for it can be expressed by all archwires; and probably more expressed by the rectangular archwire. ${ }^{5,7}$ However, in this paper, the inclination will be specifically analyzed in accordance with the proposal and methodology adopted.

The effects of prescription for inclination, together with the concept of play and biological variation, will be discussed by presentation of case reports in which 
Table 2 - Capelozza Filho ${ }^{5}$ prescription for maxillary incisor and canine brackets for treatment of Pattern I, II and III malocclusions.

\begin{tabular}{|c|c|c|c|c|c|c|c|c|c|c|}
\hline \multicolumn{11}{|c|}{$\begin{array}{ll}\text { MAXILLARY ARCH } \\
\end{array}$} \\
\hline & \multicolumn{4}{|c|}{ PATTERN II } & \multicolumn{3}{|c|}{ PATTERN I } & \multicolumn{3}{|c|}{ PATTERN III } \\
\hline & $\begin{array}{l}\text { Central } \\
\text { incisor }\end{array}$ & $\begin{array}{l}\text { Lateral } \\
\text { incisor }\end{array}$ & Canine & $\begin{array}{l}\text { Canine } \\
\text { II Plus }\end{array}$ & $\begin{array}{l}\text { Central } \\
\text { incisor }\end{array}$ & $\begin{array}{l}\text { Lateral } \\
\text { incisor }\end{array}$ & Canine & $\begin{array}{l}\text { Central } \\
\text { incisor }\end{array}$ & $\begin{array}{l}\text { Lateral } \\
\text { incisor }\end{array}$ & Canine \\
\hline Angulation & $5^{\circ}$ & $9^{\circ}$ & $5^{\circ}$ & 0 & $5^{\circ}$ & $9^{\circ}$ & $8^{\circ}$ & $5^{\circ}$ & $9^{\circ}$ & $11^{\circ}$ \\
\hline Inclination & $+7^{\circ}$ & $+3^{\circ}$ & $-5^{\circ}$ & -8 & $+7^{\circ}$ & $+3^{\circ}$ & $-5^{\circ}$ & $+14^{\circ}$ & $+10^{\circ}$ & $-2^{\circ}$ \\
\hline Projection & $1,5 \mathrm{~mm}$ & $1,9 \mathrm{~mm}$ & $1,4 \mathrm{~mm}$ & $1,4 \mathrm{~mm}$ & $1,5 \mathrm{~mm}$ & $1,9 \mathrm{~mm}$ & $1,4 \mathrm{~mm}$ & $1,5 \mathrm{~mm}$ & $1,9 \mathrm{~mm}$ & $1,4 \mathrm{~mm}$ \\
\hline
\end{tabular}

Table 3 - Capelozza Filho 5 prescription for mandibular incisor and canine brackets for treatment of Pattern I, II and III malocclusions.

\begin{tabular}{|c|c|c|c|c|c|c|c|}
\hline \multicolumn{8}{|c|}{$\begin{array}{ll}\text { MANDIBULAR ARCH } \\
\text { MAR }\end{array}$} \\
\hline & \multicolumn{3}{|c|}{ PATTERN II } & \multicolumn{2}{|c|}{ PATTERN I } & \multicolumn{2}{|c|}{ PATTERN III } \\
\hline & Incisors & Incisors Plus & Canine & Incisors & Canine & Incisors & Canine \\
\hline Angulation & $2^{\circ}$ & $2^{\circ}$ & $5^{\circ}$ & $2^{\circ}$ & $5^{\circ}$ & $0^{\circ}$ & $0^{\circ}$ \\
\hline Inclination & $+4^{\circ}$ & +8 & $-11^{\circ}$ & $-1^{\circ}$ & $-11^{\circ}$ & $-6^{0}$ & $-11^{\circ}$ \\
\hline Projection & $1,9 \mathrm{~mm}$ & $1,9 \mathrm{~mm}$ & $1,4 \mathrm{~mm}$ & $1,9 \mathrm{~mm}$ & $1,4 \mathrm{~mm}$ & $1,9 \mathrm{~mm}$ & $1,4 \mathrm{~mm}$ \\
\hline
\end{tabular}

brackets with slot $0.022 \times 0.030$-in manufactured by ABZIL were used, with individualized prescription according to the facial pattern. An alignment and leveling protocol was established up to utilization of $0.021 \mathrm{x}$ 0.025-in rectangular archwires. Cephalometric radiographs were obtained in defined intervals as follows: $\mathrm{T}_{0}$ - initial; $\mathrm{T}_{1}$ - at completion of 0.020-in leveling; $\mathrm{T}_{2}$ - 45 days after placement of $0.019 \times 0.025$-in leveling archwire; and $\mathrm{T}_{3}-45$ days after placement of 0.021 x 0.025-in leveling archwire. During this evaluation period, which comprised the 0.020-in up to $0.021 \mathrm{x}$ 0.025-in archwires, no other mechanical resource was used in combination to the leveling archwires to avoid interference. The rectangular archwires remained installed for a minimum period of 45 days, when patients were radiographed. All archwires were checked before placement and did not present any torsion that might alter the prescription of brackets.

The measurements selected to evaluate the evolution of incisors during treatment were IMPA and 1.PP. All radiographs were obtained using a single equipment, traced by a single examiner and checked by a different examiner. The tracing was then digitized and measurements were performed on a computer.

\section{Case report 1}

Female patient, aged 13 years, pattern III, presented a straight profile with mild maxillary deficiency and slight mandibular deviation to the right side. When evaluated in centric relationship, the patient presented an edge-to-edge anterior relationship. The maxillary arch exhibited crowding in the right posterior region, with lingual rotation of the maxillary right second premolar (Fig 2). The incisor inclination already demonstrated some degree of dental compensation before treatment, with 1.PP measuring $121.7^{\circ}$ and IMPA $86.8^{\circ}$.

The proposed treatment planning included maxillary rapid expansion, followed by maxillary protraction with compensatory intention since the patient was in the final growth period, with the history of menarche six months before treatment onset. Attached to the modified Haas expander, was a TMA coil of Pendex ${ }^{13}$ type for distalization of the maxillary right second molar and consequent achievement of space for the maxillary right second premolar. During maxillary protraction the mandibular leveling was initiated, using Capelozza Filho's Class III prescription, with torque of $-6^{\circ}$ for mandibular incisors since it was predicted that compensation, already present before treatment, would be increased by the applied mechanics and,at treatment completion, the mandibular incisors would present remarkably reduced inclinations. Concomitant to maxillary protraction, Class III elastics were used as part of the protocol, initially attached to the mandibular canines and later to the archwire. This was installed since the early stages of mandibular leveling to avoid any buccal tipping of mandibular incisors during leveling. ${ }^{6,7}$

In this particular case, regular prescription was used in the maxillary arch since the clinical evaluation of inclination of the buccal surfaces of the maxillary incisor crowns, 

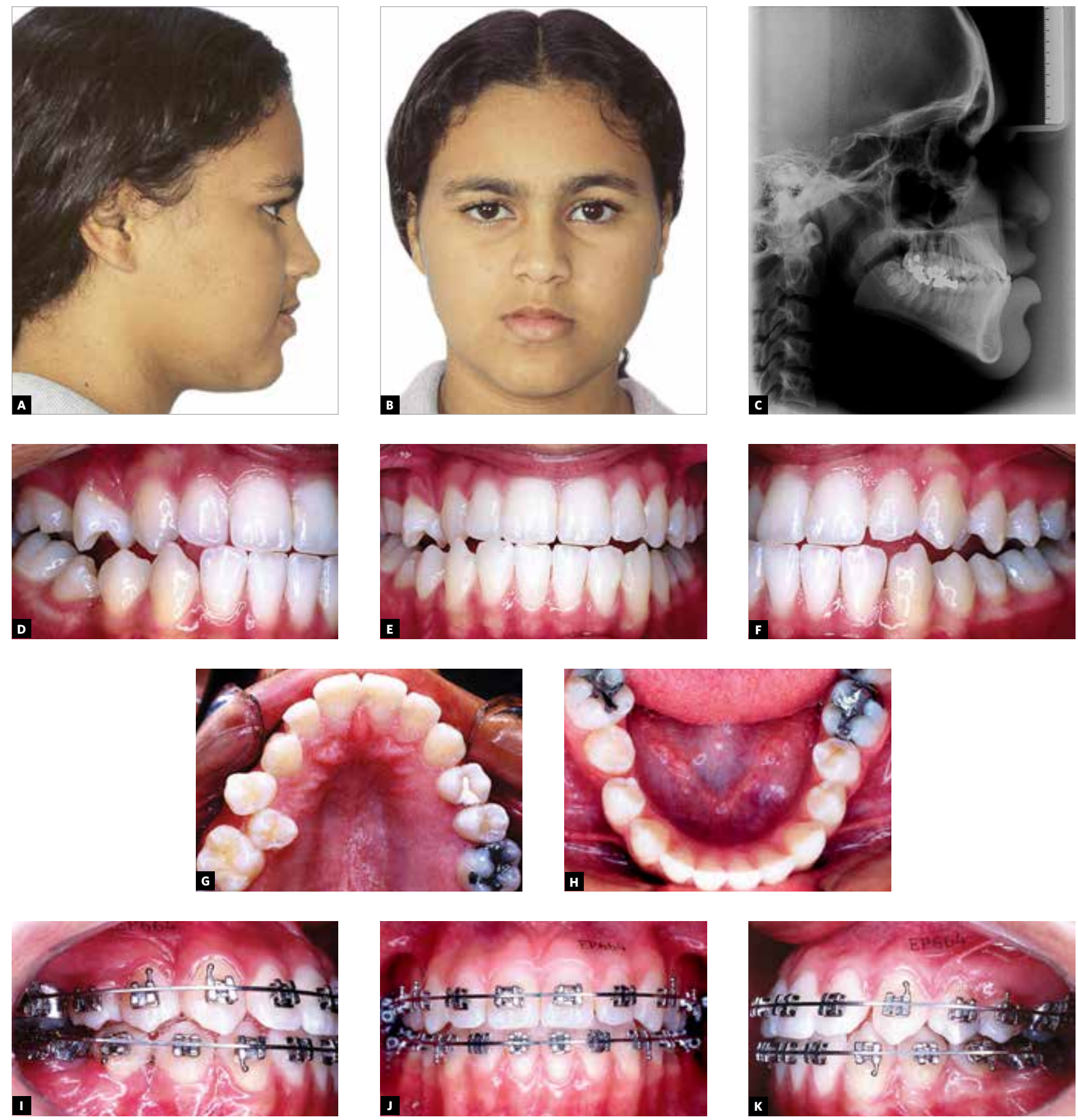

Figure 2 - Case 1: Initial records (A-H) and at placement of 0.021"x 0.025-in levelling archwire (I, J, K).

even after using the mask, did not reveal great buccal inclination to justify the use of Prescription III. This greater potential of compensation may jeopardize the facial esthetics by elevating the anterior occlusal plane and closing the nasolabial angle,hence it should be avoided in Caucasoid patients when possible.,

The maxillary and mandibular leveling was continued up to $0.021 \times 0.025$-in archwire. The evolution of incisors during the different stages of leveling is presented in Figure 3. Comparison of the initial radiograph $\left(\mathrm{T}_{0}\right)$ with the one obtained at completion of 0.020-in leveling $\left(\mathrm{T}_{1}\right)$ clearly demonstrates the influence of elastics mechanics associated to maxillary protraction on the mandibular incisors, promoting an IMPA reduction of $3.6^{\circ}$, from $86.8^{\circ}$ to $83.2^{\circ}$. The inclination of maxillary incisors was nearly unaltered during this stage. The introduction of $0.019 \times 0.025-$ in archwire promoted buccal inclination in maxillary 
incisors and nearly did not alter the inclination of mandibular incisors. With the introduction of 0.021 $\mathrm{x}$ 0.025-in leveling archwire, there was a reduction of $1.2^{\circ}$ in the inclination of maxillary incisors and increase of $1.1^{\circ}$ in the inclination of mandibular incisors. Considering the concept of play between the slot and the bracket, it is easy to explain the evolution of mandibular incisors, which presented a more negative inclination than the $-6^{\circ}$ prescription contained in the bracket at completion of 0.020 -in leveling. Introduction of the $0.019 \times 0.025$-in archwire did not have a significant effect in inclination, possibly due to the great play between this archwire and the slot. With introduction of the $0.021 \times 0.025$-in archwire, reduction of the play promoted an active positive torque, which was responsible for the IMPA change. The Class III prescription in this case was effective to avoid undesirable effects with the $0.019 \times 0.025$-in archwire, yet still insufficient to avoid the undesirable buccal inclination for Class III correction when using the 0.021 $x$ 0.025-in archwire. However, the amount of torque promoted by the $0.021 \times 0.025$-in archwire did not lead to the loss of overjet correction. It is more difficult to explain the evolution of the maxillary incisor, which exhibited buccal tipping with utilization of the 0.019 $x$ 0.025-in archwire and then palatal inclination when using the $0.021 \times 0.025$-in archwire. The most probable explanation is that the buccal inclination of maxillary incisors occurred during $0.019 \times 0.025$-in leveling is that it might have been a side effect of torque correction on the posterior teeth. After maxillary rapid expansion; the posterior teeth were strongly buccally inclined, hence the reduction of transverse dimensions of the maxillary arch by palatal inclination of posterior teeth may have led to an increase in arch length (buccal inclination of incisors) to maintain a constant perimeter (sum of mesiodistal size of aligned maxillary teeth without crowding). The play existing when using the $0.019 \times 0.025$ in archwire allowed buccal inclination of the maxillary incisor up to the play extent. With introduction of the $0.021 \mathrm{x}$ 0.025-in archwire, the play reduction promoted an active negative torque, reducing the 1.PP (Fig 3).

An important consideration in this case is that, if a regular prescription was used in the mandibular arch, introducing angulations for the anterior teeth, such a significant reduction in IMPA would hardly be achieved up to 0.020 -in leveling. The torque would also be concerning, considering the mandibular incisors crowns presented a torque lower than $-6^{\circ}$, which was confirmed after introduction of the $0.021 \times 0.025$ in archwire. The use of regular prescription for inclination $\left(-1^{\circ}\right)$ might cause an active positive torque of the crown when introducting the $0.019 \times 0.025$-in archwire, and the use of a $0.021 \times 0.025$-in archwire with regular prescription might have led to loss of anterior relationship. The use of other mechanical resources to avoid this,could have unfavorable effects on the roots and supporting bone relationship.

\section{Case report 2}

Female patient, aged 12 years, Pattern II, presenting mandibular deficiency evidenced by a short chin-neck line and marked mentolabial sulcus. The intraoral examination evidenced maxillary atresia, which however

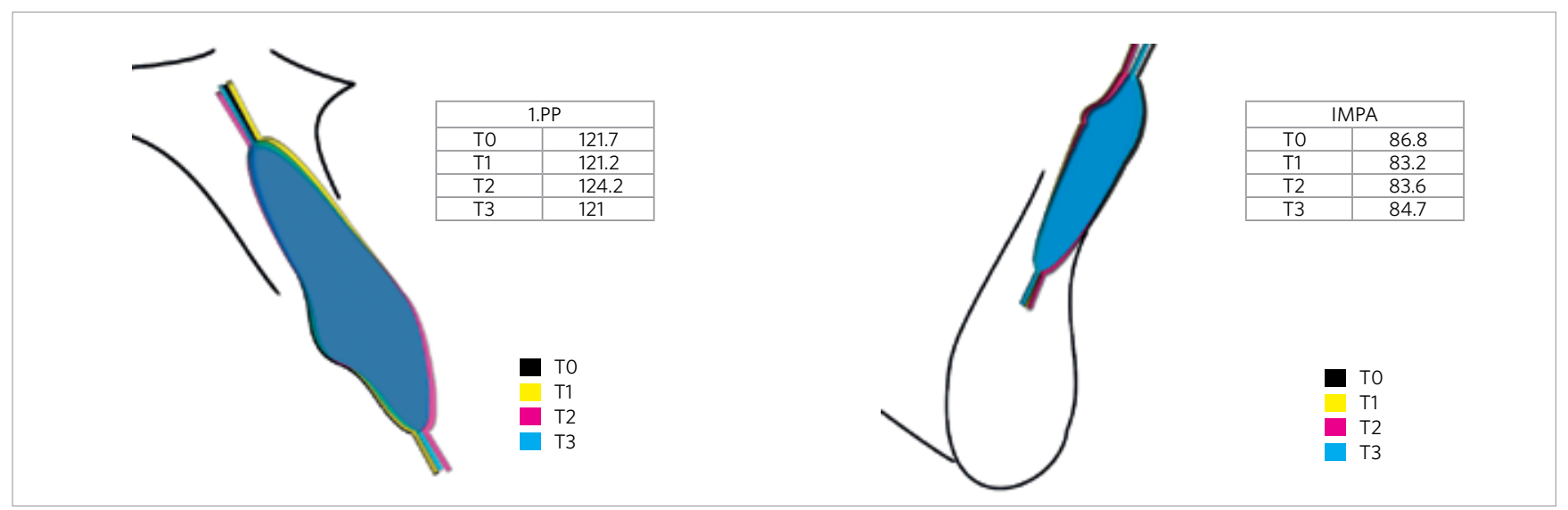

Figure 3 - Cephalometric superimposition of IMPA and 1.PP evolution from initial leveling up to $0.021 \times 0.025$-in archwire. $T_{0}-$ Initial, $T_{1}-$ After leveling with 0.020-in archwire, $T_{2}$ - After leveling with $0.019 \times 0.025$-in archwire, $T_{3}$ - After leveling with $0.021 \times 0.025$-in archwire. 
did not lead to posterior crossbite because it was combined with atresia of the mandibular dental arch. This atresia of both arches caused tooth crowding in both maxillary and mandibular arches. The Class II interarch relationship was coincident with the facial pattern. Analysis of the initial cephalogram $\left(\mathrm{T}_{0}\right)$ demonstrated maxillary and mandibular incisors well-positioned in their bone bases; with $111.2^{\circ}$ for 1.PP and $93.5^{\circ}$ for IMPA.
The proposed treatment plan included initially the reestablishment of dental arch morphology by means of a maxillary rapid expansion and slow mandibular arch expansion using an expanded lip bumper. After transverse correction, compensatory correction of malocclusion in the sagittal plane was initiated. This correction used an extra-oral anchorage for distalization of the maxillary first molars and prescription II,
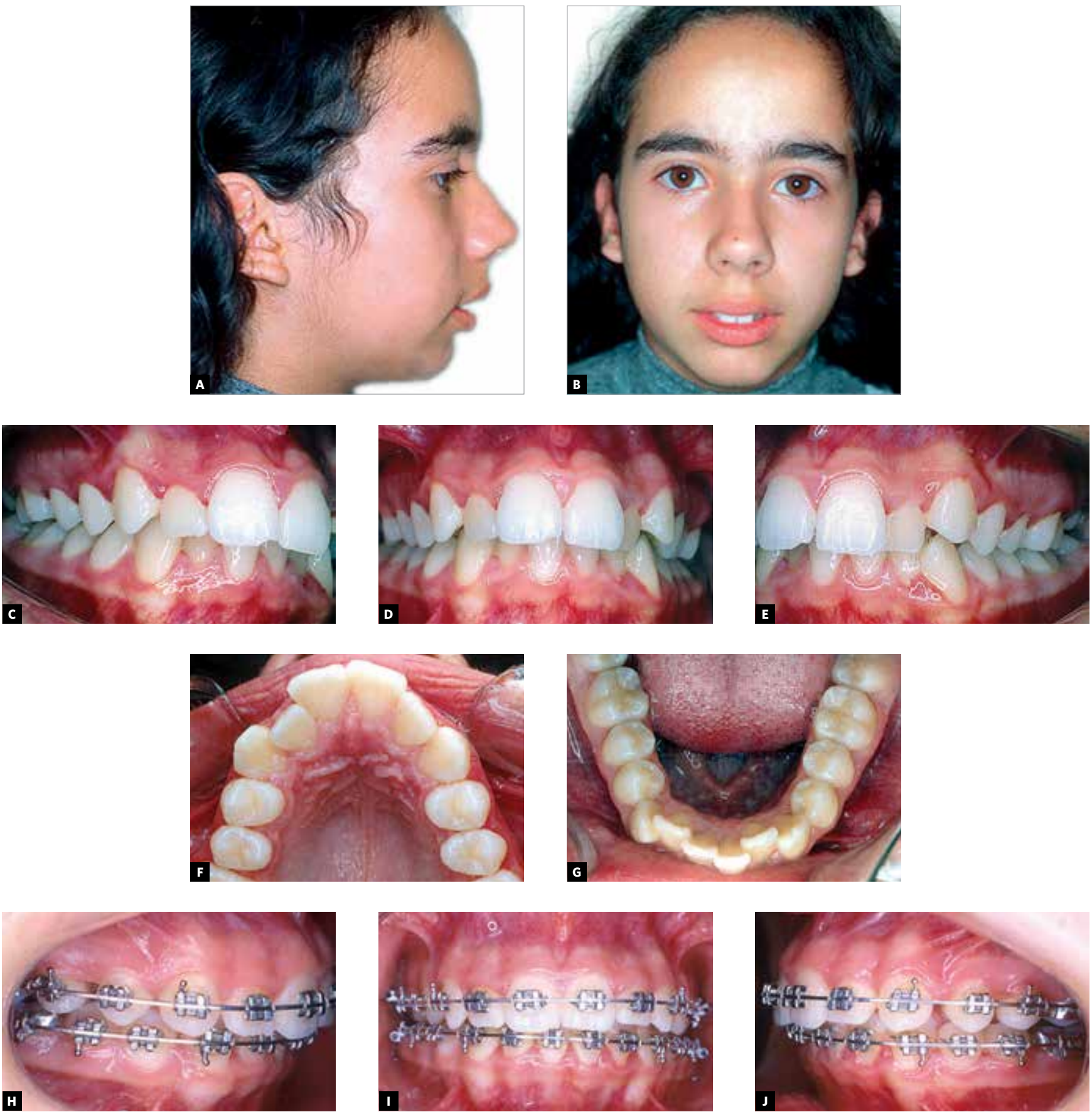

Figure 4 - Case 2: Initial records (A-G) and at placement of $0.021 \times 0.025$-in levelling archwire $(\mathbf{H ,} \mathbf{I}, \mathbf{J})$. 
since the prediction for finishing indicated that the mandibular incisors would maintain or even increase their degree of buccal inclination. The crowding would be relieved by transverse expansion in both arches and sagittal expansion by distalization of maxillary molars and protrusion of mandibular incisors.

The radiographic evaluation after 0.020-in leveling $\left(\mathrm{T}_{1}\right)$ revealed an increase of $4^{\circ}$ (from $93.5^{\circ}$ to $97.5^{\circ}$ ) in the inclination of mandibular incisors, a reflex of the expansion mechanics applied. The slight increase in the maxillary incisors inclination (1.PP went from $111.2^{\circ}$ to $\left.111.9^{\circ}\right)$ suggests that the expansion mechanics in the maxillary arch caused more transverse expansion and distalization of maxillary molars.

The effects of leveling with $0.019 \times 0.025$-in archwire, demonstrated by comparison of cephalograms at $\mathrm{T}_{2}$ and $\mathrm{T}_{1}$, indicated an increase of $1.1^{\circ}$ (from $111.9^{\circ}$ to $113.0^{\circ}$ ) in the inclination of maxillary incisors. The mandibular arch nearly did not present changes by introduction of the $0.019 \times 0.025$-in archwire. The leveling protocol was continued by introduction of $0.021 \times 0.025$-in leveling archwire. Comparison of 1.PP and IMPA values from the cephalograms at $\mathrm{T}_{3}$ and $\mathrm{T}_{2}$ allows to infer the actual effect of the leveling with $0.021 \times 0.025$-in rectangular archwires. These effects, in this patient, were reduction of buccal inclination of both maxillary and mandibular incisors.

The explanation for the evolution of the maxillary incisors inclination in this case (Fig 4), that first were buccally inclined in $1.1^{\circ}$ by introduction of the $0.019 \times 0.025$-in archwire, then lingually tipped in $0.7^{\circ}$ with the increase in the dimension of the rectangular archwire (0.021 x 0.025 ”), may be explained, similarly to case 1: As an interference of posterior teeth torque correction on the incisor inclination after the patient was submitted to maxillary rapid expansion.

In the mandibular arch, introduction of the $0.021 \mathrm{x}$ 0.025-in archwire promoted great negative torque and the outcome was an IMPA reduction of $3.4^{\circ}$ (from $97.3^{\circ}$ to $93.9^{\circ}$ ). The force binary acting on the crown and the impossibility to promote lingual movement of the crown due to lack of space, caused buccal movement of the root, pushing it against the buccal cortical plate. This highly undesirable movement due to its iatrogenic potential, ${ }^{12}$ fortunately, did not cause negative consequences in this case. It should be noted that even a prescription aiming to allow greater buccal inclination of the mandibular incisor was not sufficient for the degree of compensation exhibited by these teeth. The result might have been even greater if a regular prescription (- $\left.1^{\circ}\right)$ was used. Prescriptions with individualization for movement, such as MBT $\left(-6^{0}\right),{ }^{15}$ might cause even worse consequences. Considering that, the torque values published by Creekmore, ${ }^{10}$ revealed a difference in play between $0.019 \times 0.025$-in and $0.021 \times$ 0.025-in archwires of $6.6^{\circ}$ and that in this case the clinically more significant torque was produced by the 0.021 $x$ 0.025-in archwire, the difference of $5^{\circ}$ between the regular prescription $\left(-1^{\circ}\right)$ and the Class II prescription $\left(+4^{\circ}\right)$ might promote active torques with clinical significance early in the $0.019 \times 0.025$-in archwire. If brackets with $-6^{\circ}$ torque were used, the negative torque effects would certainly manifest early in the $0.019 \times 0.025$-in archwire. This would surely be highly undesirable, since unlike the $0.021 \times 0.025$-in archwire, the $0.019 \times 0.025$-in

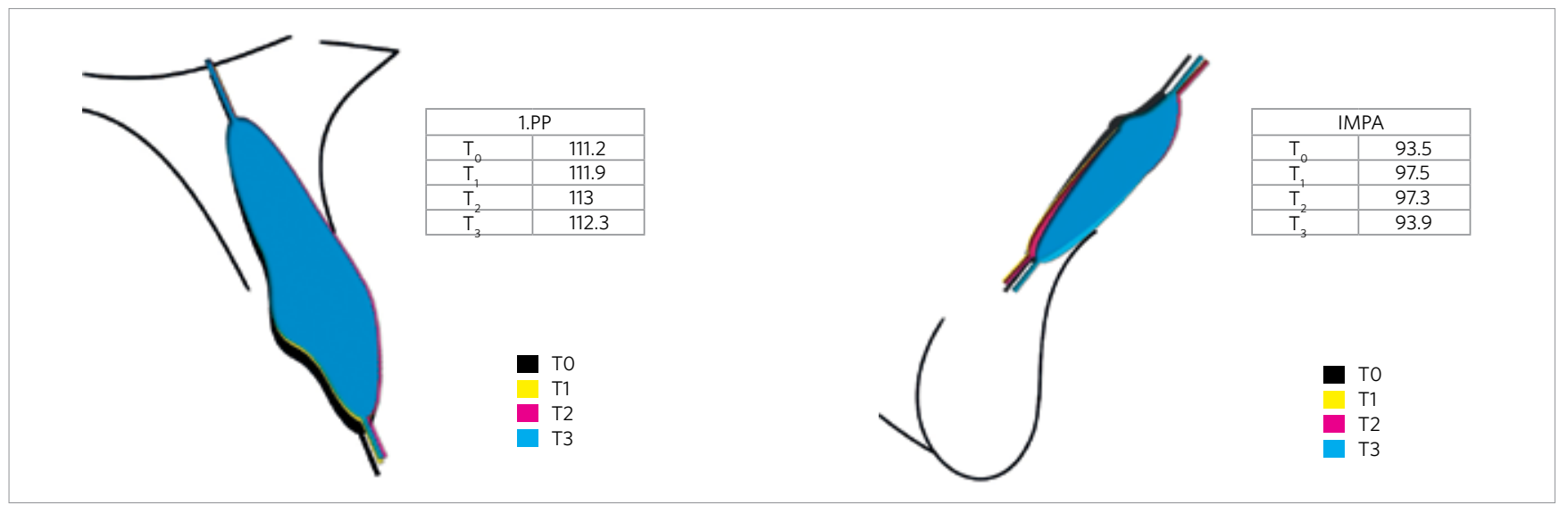

Figure 5 - Cephalometric superimposition of IMPA and 1.PP evolution from initial leveling up to $0.021 \times 0.025$-in archwire. $T_{0}-$ Initial, $T_{1}-$ After leveling with 0.020-in archwire, $T_{2}$ - After leveling with $0.019 \times 0.025$-in archwire, $T_{3}$ - After leveling with $0.021 \times 0.025$ "archwire. 
archwire is routinely employed and usually remains engaged to the brackets for longer period than adopted in the present study. Moreover, intermaxillary elastics are usually employed with this archwire. The use of Class II elastics in an archwire with active negative torque would further increase the buccal movement of the root, since the force applied by the elastics would act on the crown pushing it in the buccal direction, and the active negative torque would promote a force binary to lingually incline the crown. The resulting force would then produce buccal movement of the root pushing it against the buccal cortical plate, and the extension of root movement would be related to the quantity of force generated by the intermaxillary elastics. This is at least unintelligent.

The classical torque proposal, when Class II intermaxillary elastics are used, is that there should be resistant negative torque in mandibular incisors as an attempt to minimize the buccal inclination of incisors and use the buccal surfaces of the mandibular incisors roots as part of the anchorage unit, when elastics are being used to assist the maxillary anterior retraction, for example. Some prescriptions, as the MBT, ${ }^{15}$ intent to include this torque in the mandibular incisors brackets altering the value to $-6^{\circ}$. However, the concept of resistant torque is relative, and the torque present in the bracket is only one of the factors that will determine the type of torque produced;it should also be considered the crown's initial buccal inclination and the amount of play between archwire and slot. In the present case, the 0.019 x 0.025-in archwire effect of not altering significantly the IMPA demonstrates a resistant negative torque, since the crown presented greater torque than the one existing in the bracket, which was only confirmed after the introduction of the $0.021 \times 0.025$-in archwire caused IMPA reduction. This evidences that, to determine which degree of torque a tooth will receive with a certain prescription, it is also necessary to evaluate the inclination present in the buccal surface of the tooth crown.

Some concepts, widely used regarding torque in the conventional Edgewise philosophy, should be revisited and better understood to be adapted to the Sraight-Wire philosophy.

In the conventional Edgewise philosophy, actual torque was that applied to the archwire and checked with pliers, and could be considered as neutral, buccal or lingual, according to the region where the archwire passed when held by the plier. This same archwire, when inserted in a bracket, delivered the so-called relative torque, which was the most important one, since the interaction between the torque in the archwire and the crown inclination determined the actual effect that would be achieved. Therefore, the relative torque could be considered passive, resistant or active.

In the straight wire philosophy these concepts had to be revised, because of the proposal to include in the bracket the positioning characteristics that were previously applied to the archwire. Thus, in the straight wire, the actual torque is present in the bracket, yet the most important factor is still the relative torque, which is measured in relation to the crown inclination. Similarly to the conventional Edgewise philosophy, the clinical observation of the archwire position when inserted into the bracket may be used to check the relative torque. However, with better understanding on the concepts of play and force reduction, a new manner of explaining passive, resistant and active torques may be employed. Whenever a rectangular archwire is inserted into a bracket whose crown inclination is contained in the play interval of the archwire, this torque may be considered passive since it will not promote any inclination movement. When the crown inclination is greater than the play limit, yet within a small range above and below the play interval, in which the resulting force binary is not intense enough to produce movement, this torque might be considered as resistent. When the crown inclination is out of the play range, generating a binary with sufficient force intensity to produce tooth movement, this torque may be considered active. However, the mathematical application of this concept is difficult, since most manufacturers of orthodontic materials do not disclose the play values existent between their bracket and archwire set, and investigations conducted so far were unable to measure the force reduction. Notwithstanding, the acceptance of this explanation may guide the professional during utilization of rectangular archwires, allowing a more accurate estimate of third order binaries generated between the archwire and the slot.

\section{Concluding remarks}

Evaluation of incisor inclination during leveling with different rectangular archwires sizes in cases of compensatory treatments allows the following conclusions:

- In compensatory treatments, the bracket-archwire play, though considered a deficiency in the Edgewise techniques (including the Straight-Wire), 
may be considered a factor that allow occlusal correction without undesirable movements, even when using partially individualized brackets;

- Additionally, the accurate indication of bracket-archwire play values by the manufacturer would allow to the orthodontist a more effective torque control in Straight-Wire appliances;

- When using individualized brackets for finishing, leveling with $0.019 \times 0.025$-in archwire did not promote significant alterations in the maxillary and mandibular central incisors inclinations;

Considering that the difference in play between $0.019 \times 0.025$-in and $0.021 \times 0.025$-in archwires is $6.6^{\circ}$ $(\text { Creekmore })^{10}$ and the difference between regular and individualized prescription for mandibular incisors in the employed prescription ${ }^{5}$ is $5^{\circ}$, the following could be expected:
- Active lingual torques early in 019 x 0.025-in archwire leveling if regular or individualized brackets for movement were used, especially in Pattern II patients.

- The use of $0.021 \times 0.025$ archwires caused changes in inclinations, especially in mandibular incisors, opposite to the compensation direction, despite the employment of brackets with compensatory torques.

- Considering the present conditions of individualized brackets for inclination in the StraightWire technique, always allowing the possibility of using rectangular archwires, though not mandatory, it seems obvious the choice of rectangular archwire and brackets with play greater than minimum, such as $0.019 \times 0.025$-in archwire in $0.022 \times 0.030$-in slot.

\section{REFERENCES}

1. Alexander RG. The vari-simplex discipline. Part 1. Concept and appliance design. J Clin Orthod. 1983 Jun;17(6):380-92.

2. Andrews LF. Straight wire: o conceito e o aparelho. 2a ed. San Diego: L. A. Wells; 1996

3. Bibby RE. Incisor relationships in different skeletofacial patterns. Angle Orthod. 1980 Jan;50(1):41-4.

4. Cabrera CAG, Freitas MR, Janson G, Henriques JFC. Estudo da correlação do posicionamento dos incisivos superiores e inferiores com a relação ânteroposterior das bases ósseas. Rev Dental Press Ortodon Ortop Facial. 2005 NovDez;10(6):59-74.

5. Capelozza Filho L. Individualização de braquetes na técnica de straight-wire: Revisão de conceitos e sugestão de indicações para uso. Rev Dental Press Ortodon Ortop Facial. 1999 Jul-Ago:4(4):87-106.

6. Capelozza Filho L. Quais seriam as atuais considerações sobre a performance da prescrição Capelozza na clínica ortodôntica? Rev Clín Ortodon Dental Press. 2002 Abr-Maio; 1(2):23-4

7. Capelozza Filho L. Diagnóstico em Ortodontia. Maringá (PR): Dental Press; 2004.

8. Casko JS, Shepherd WB. Dental and skeletal variation within the range of normal. Angle Orthod. 1984 Jan;54(1):5-17.

9. Creekmore TD, Kunik RL. Straight wire: The next generation. Am J Orthod Dentofacial Orthop. 1993 Jul;104(1):8-20. Erratum in: Am J Orthod Dentofacial Orthop $1993 \mathrm{Nov} ; 104(5): 20$

10. Creekmore TD. JCO interviews: Dr Thomas D. Creekmore on torque. J Clin Orthod 1979 May;13(5):305-10

11. Dellinger EL. A scientific assessment of the straight-wire appliance. Am J Orthod. 1978 Mar;73(3):290-9.

12. Handelman CS. The anterior alveolus: its importance in limiting orthodontic treatment and its influence on the occurrence of iatrogenic sequelae. Angle Orthod. 1996;66(2):95-109; discussion 109-10.
13. Hilgers JJ. The pendulum appliance for Class II non-compliance therapy. J Clin Orthod. 1992 Nov;26(11):706-14.

14. Hixson ME, Brantley WA, Pincsak JJ, Conover JP. Changes in bracket slot tolerance following recycling of direct bond metallic orthodontic appliances. Am J Orthod. 1982 Jun;81(6):447-54.

15. McLaughlin R, Bennett J, Trevisi H. O sistema do aparelho versátil MBT: O desenvolvimento de uma mecânica e filosofia de tratamento - Parte I. Rev Dental Press Ortodon Ortop Facial. 1998 Maio-Jun;3(3):15-23.

16. Meling TR, Odegaard J, Seqner D. On bracket slot height: a methodologic study. Am J Orthod Dentofacial Orthop. 1998 Apr;113(4):387-93.

17. Ricketts RM. Bioprogressive therapy as an answer to orthodontic needs. Part I. Am J Orthod. 1976 Sep;70(3):241-68.

18. Roth RH. Roth straight wire appliance philosophy. San Diego (CA): "A-in Company; 1979.

19. Sebanc J, Brantley WA, Pincsak JJ, Conover JP. Variability of effective root torque as a function of edge bevel on orthodontic arch wires. Am J Orthod. 1984 Jul;86(1):43-51

20. Solow B. The dentoalveolar compensatory mechanism: Background and clinical implications. Br J Orthod. 1980 Jul;7(3):145-61.

21. Uğur T, Yukay F. Normal faciolingual inclinations of tooth crowns compared with treatment groups of standard and pretorqued brackets. Am J Orthod Dentofacial Orthop. 1997 Jul;112(1):50-7.

22. Vardimon $A D$, Lambertz W. Statistical evaluation of torque angles in reference to straight-wire appliance (SWA) theories. Am J Orthod. 1986 Jan;89(1):56-66. 